\title{
Direct Reduction Recycling of Mill Scale Through Iron Powder Synthesis
}

\author{
Kameswara Srikar SISTA, ${ }^{*}$ Srinivas DWARAPUDI and Virendra Prakash NERUNE \\ R\&D Tata Steel, Jamshedpur-831001, Jharkhand, India. \\ (Received on September 14, 2018; accepted on December 10, 2018; J-STAGE Advance published \\ date: February 14, 2019)
}

\begin{abstract}
Mill scale, a potential raw material for recycling from hot rolling mill operations is chosen and one step thermo-chemical reduction technique is employed to beneficiate the iron content in the form of powdered iron. Experiments are conducted at various temperature $\left(600-1300^{\circ} \mathrm{C}\right)$ and time $(1-4 \mathrm{~h})$ combinations using hydrogen as reducing atmosphere. Physical and chemical properties of mill scale iron powders (MIP) are analysed using particle size analyser, gas pycnometer and wet chemical testing. MIP are also characterized for phase and morphology using X-ray diffractometer and scanning electron microscopy respectively. Effect of parameters like temperature of reduction, time of reduction, particle size of raw material, sintering and grinding on the iron powder synthesis is well studied. Mill scale iron powder with $>99 \%$ degree of metallization, 97\% Fe (T), > 96\% Fe (met) and $2.63 \mathrm{~g} / \mathrm{cc}$ apparent density is obtained at $1200^{\circ} \mathrm{C}, 4 \mathrm{~h}$ and $1300^{\circ} \mathrm{C}, 4 \mathrm{~h}$ parameters and this material would stand promising for recycling through nutrition supplements, body warmers, water purification, sound insulators, etc applications.
\end{abstract}

KEY WORDS: mill scale; recycling; reduction; iron powder.

\section{Introduction}

Integrated steel plant operations generate large amounts of solid wastes which sums to about 400-500 Kg per ton of steel produced. ${ }^{1-3)}$ Major solid wastes comprise of LD slag, BF slag, BF flue dust, LF slag, Mill scale, LD sludge, BF sludge, etc. Now-a-days, due to increasing environmental regulations as well as depleting iron ores, management of wastes, i.e. to utilize and convert them into either valueadded products or secondary raw materials is of prime concern. In this scenario, the terminology of "industrial wastes" has been changed to "industrial by-products" due to their possibility of re-utilization using thermal, metallurgical and physical beneficiation processes rather than dumping them as a waste. ${ }^{4)}$ By-products bearing high iron content such as, mill scale, LD sludge and BF dust are more attractive in comparison with low iron bearing materials like slags. One such attractive material to explore is mill scale obtained from hot rolling mill operations.

Mill scale, generally obtained in the size range of 1-5 $\mathrm{mm}$, comprises of about $70 \%$ iron in the form of hematite $\left(\mathrm{Fe}_{2} \mathrm{O}_{3}\right)$, magnetite $\left(\mathrm{Fe}_{3} \mathrm{O}_{4}\right)$, Wustite $(\mathrm{FeO})$ and metallic iron (Fe) along with traces of other nonferrous material and alkaline impurities. ${ }^{5,6}$ The chemical composition of mill scale varies depending on the quality and composition of steel being made during the generation of mill scale at source. Recycling of mill scale can be done using best of the five major recycling techniques, generally used for waste

\footnotetext{
* Corresponding author: E-mail: sista.srikar@tatasteel.com DOI: https://doi.org/10.2355/isijinternational.ISIJINT-2018-628
}

recycling in integrated steel plant operations, such as use in sintering, by cold bonded agglomeration, by injection, by direct reduction and by smelting reduction. The choice the recycling technique depends on factors such as environment, energy, policy, industrial statues, recycling strategy of industry, feasibility, technology readiness and economics.

Earlier, mill scale was injected as an oxidizer in conventional electric arc furnace, which is outdated by introduction of oxygen lancing. Habitual usage of mill scale in iron making, through sintering process is widely reported, ${ }^{7,8)}$ but this process has its own disadvantages of deteriorating the sinter bed permeability, productivity and finally sinter quality. ${ }^{8,9)}$ Eissa and co-workers reported the recycling of mill scale by smelting process to obtain various iron bearing valuable products. ${ }^{9)}$ Recycling by cold bonded agglomeration in the form of pellets and briquettes to iron and steel making operations is very well-known technique and notable research is being conducted till date by many researchers worldwide. ${ }^{1,2,10-12)}$ Cold bonded agglomeration in combination with direct reduction technique was also explored by few researchers. ${ }^{3,13)}$ Direct reduction recycling is one such technique which is less explored. Literature showcasing direct reduction recycling of mill scale is tabulated in the Table 1. One of the major outcomes of direct reduction recycling technique of mill scale is a high value product termed as iron powder which has plethora of applications and market in the fields of powder metallurgy, friction materials, electronic components, magnetic materials, microwave absorption, deoxidizing materials, metal injection moulding, welding materials, diamond tools, gas cutting agents, nutrition supplements, body warmers, ground 
Table 1. Direct recycling of Mill scale.

\begin{tabular}{|c|c|c|c|c|c|}
\hline S. No & Author, Year & Raw Material & Parameters & Recycling Technique & Ref \\
\hline 1 & Martin et al., 2012 & Mill Scale & $\begin{array}{l}\text { Reducing agent: Coke } \\
\text { Temp: } 1050-1150^{\circ} \mathrm{C} \text {. } \\
\text { Time: } 3-12 \mathrm{~h} .\end{array}$ & Direct reduction & {$[5]$} \\
\hline 2 & Sen et al., 2015 & Mill scale & $\begin{array}{c}\text { Reducing agent: Low grade coal } \\
\text { Temp: } 900^{\circ} \mathrm{C} \text {. } \\
\text { Time: } 30-90 \mathrm{~min} .\end{array}$ & Direct Reduction. & {$[6]$} \\
\hline 3 & Benchiheub et al., 2010 & Mill scale & $\begin{array}{c}\text { Reducing agent: Carbon monoxide gas } \\
\text { Temp: } 750-1050^{\circ} \mathrm{C} \text {. } \\
\text { Time: } 40-180 \mathrm{~min}\end{array}$ & Direct Reduction & {$[15]$} \\
\hline 4 & Ye et al., 2013 & Mill scale & $\begin{array}{l}\text { Reducing agent: Wood charcoal } \\
\text { Temp- } 1050-1150^{\circ} \mathrm{C} . \\
\text { Time- } 20-60 \mathrm{~min} . \\
\text { Microwave heating }\end{array}$ & Direct reduction & [16] \\
\hline 5 & Ye et al., 2014 & Mill scale & $\begin{array}{c}\text { Reducing agent: Wood charcoal } \\
\text { Temp: } 1150^{\circ} \mathrm{C} \text {. } \\
\text { Time:5 and } 50 \mathrm{~min} . \\
\text { Microwave heating }\end{array}$ & Direct reduction & [17] \\
\hline 6 & Mechachti et al., 2013 & Mill Scale & $\begin{array}{l}\text { Reducing agent: Carbon Monoxide gas } \\
\text { Temp: } 750-1050^{\circ} \mathrm{C} \text {. } \\
\text { Time: } 40-180 \mathrm{~min} .\end{array}$ & Direct reduction & [18] \\
\hline 7 & Joshi and Dhokey, 2015 & Mill scale & $\begin{array}{l}\text { Reducing agent: Hydrogen gas } \\
\text { Temp: } 700-1100^{\circ} \mathrm{C} \text {. } \\
\text { Time: } 0.5-4 \mathrm{~h} .\end{array}$ & Direct Reduction & [19] \\
\hline 8 & Shi et al., 2008 & Mill scale & $\begin{array}{c}\text { Reducing agent: Carbon monoxide gas } \\
\text { Temp: } 710-770^{\circ} \mathrm{C} \text {. } \\
\text { Time: } 60-240 \mathrm{~min} .\end{array}$ & Direct reduction & [20] \\
\hline 9 & Cho and Lee, 2008 & Mill Scale & $\begin{array}{l}\text { Reducing agent: Graphite } \\
\text { Temp: } 1100^{\circ} \mathrm{C} \text {. } \\
\text { Time: } 0-4 \text { min } \\
\text { Microwave heating }\end{array}$ & Direct reduction & [21] \\
\hline 10 & Guan et al., 2014 & Mill scale & $\begin{array}{l}\text { Reducing agent: Hydrogen gas } \\
\text { Temp: } 370-550^{\circ} \mathrm{C} \\
\text { Time: } 0-50 \mathrm{~min}\end{array}$ & Direct reduction & [22] \\
\hline
\end{tabular}

remediation, chemical reagents, water purification, sound insulators, etc. Use of steel industry by-product like mill scale for iron powder synthesis is reported. ${ }^{14)}$ Benchiheub and co-workers reported the synthesis of iron powders with $98.4 \%$ total $\mathrm{Fe}$, from mill scale to cater powder metallurgy applications. ${ }^{15)}$ Synthesis of iron powders with $98.6 \%$ and $98.56 \%$ total $\mathrm{Fe}$, from mill scale using wood charcoal as reducing agent and microwave heating is also reported. ${ }^{16,17)}$ Iron powder synthesis with $98.4 \%$ total $\mathrm{Fe}$, from mill scale by using carbon monoxide as gaseous reducing agent is reported by Mechachti and co-workers. ${ }^{18)}$ In a similar way Joshi and Dhokey also reported the direct reduction of mill scale using hydrogen gas to produce iron powders with $90 \%$ purity for usage in powder metallurgy but most of study is focused towards reaction kinetics. ${ }^{19)}$

Many works reported earlier dealt with direct reduction recycling of mill scale, but no elaborate work in relation with one step direct reduction recycling of mill scale with pure hydrogen is reported. Present work reports the study on one step reduction behaviour of mill scale with pure hydrogen gas. Optimum parameters of reduction, temperature and time dependency, raw material particle size dependency, composition and morphology variations of the obtained product at various parameters are studied. Here, the recycling is not only meant to utilize the iron content obtained after reduction for in plant process, but also opens a new product line in the form of powdered iron famously called as "iron powder".

\section{Experimental Work}

\subsection{Material}

De-oiled rolling mill scale generated within Tata Steel works is collected, dried, ground to minus 150 micron size and stored in a safe and dry location. $99.95 \%$ pure XL grade hydrogen gas and $99.99 \%$ pure nitrogen gas is procured from Linde gases limited, India.

\subsection{Method}

Around $175 \mathrm{~g}$ of mill scale is charged into a semi cylindrical alumina crucible, properly weighed and subjected to thermochemical reduction using a Carbolite make tube furnace. Nearly 40 experiments are performed to find the optimum temperature and time of reduction for conversion of mill scale into pure iron powder. The reduction temperature is varied in the range of $600-1000^{\circ} \mathrm{C}$ and the time of reduction is kept in the range of $1-4 \mathrm{~h}$, rest all parameters like, gas flow rate and sample quantity are kept constant. Reduction is carried out at a chosen temperature using gaseous hydrogen and the pre-heating and cooling cycles are carried out in an inert nitrogen atmosphere. Mill scale iron powder (MIP) after reduction is obtained in the form of either loose 
powder or slightly sintered cake or strongly sintered cake depending on the temperature of reduction. Obtained cake is ground to minus 100 microns by simple hand grinding using pistil and mortar and stored for further analysis.

\subsection{Characterization and Analysis}

Mill scale raw material and Iron powder samples obtained at different process parameters are subjected to physical (particle size, apparent density and True density) and chemical analysis. Particle size analysis is performed using $\mathrm{X}$-Dry-Camsizer-XT, true density is obtained from gas pycnometer- Accupyc II 1360 and apparent density is measured using Hall's flow meter. Powders are characterized for compound identification using Panalytical- X'Pert PRO- X-ray diffraction equipment and for morphology using FEI Quanta FEG 650 and Hitachi TM3030 Plus scanning electron microscopy. Wet chemical analysis is performed to obtained the chemical analysis results of the samples.

\section{Results and Discussion}

Chemical analysis results of mill scale shown in the Table 2, reveals that the metallic iron content in the raw material is almost negligible, confirming the presence of iron majorly in the form of oxides. Physical parameters such as true density and apparent density is also shown in the Table 2. Particle size distribution reveals that $90 \%$ of the particles are below 150 micron size.

X-ray diffraction results shown in the Fig. 1, reveals that the raw material comprises of all the three oxides of iron, i.e. Hematite $\left(\mathrm{Fe}_{2} \mathrm{O}_{3}\right)$, magnetite $\left(\mathrm{Fe}_{3} \mathrm{O}_{4}\right)$ and Wustite $(\mathrm{FeO})$.

The morphology of the raw material as shown in the scanning electron micrograph in the Fig. 2, showcases the irregular and less porous structure of mill scale particles. This conveys the difficulty in reduction of mill scale using regular reduction agents like, coal, coke, graphite, $\mathrm{CO}$ gas, etc. Literature reported discloses that, reduction of mill scale with carbonaceous solid or gaseous reducing agents, produces iron powder with maximum of $85.5 \% \mathrm{Fe}$ (Met $)^{6,10,15)}$ while further annealing in hydrogen improves the purity to $97.2 \% \mathrm{Fe}$ (Met). ${ }^{18)}$ This reveals the advantage hydrogen have over other reducing agents to reduce sparsely-porous compound like mill scale effectively. This advantage is due to high penetration tendency of gaseous hydrogen into the pores of the raw material during the process of reduction. Further advantages of using hydrogen gas for iron oxide reduction, over $\mathrm{CO}$ gas is well explained by Wagner et al. $^{23)}$

Chemical analysis results of MIP synthesized at various temperature and time combinations is shown in the Table

Table 2. Chemical and physical analysis of Mill Scale.

\begin{tabular}{ccccccccccc}
\hline \multicolumn{10}{c}{ Chemical Analysis } \\
\hline Fe (T) & FeO & Fe (MET) & $\mathrm{CaO}$ & $\mathrm{SiO} 2$ & $\mathrm{~S}$ & $\mathrm{MnO}$ & $\mathrm{Al} 2 \mathrm{O} 3$ & $\mathrm{C}$ & $\mathrm{P}$ \\
\hline 72.12 & 46.82 & 1.78 & 0.62 & 0.55 & 0.006 & 0.47 & 0.22 & 0.125 & 0.057 \\
\hline \multicolumn{7}{c}{ Physical Analysis } \\
\hline \multicolumn{7}{c}{ True Density (g/cc) } & Apparent Density (g/cc) \\
\hline \multicolumn{5}{c}{5.41} & \multicolumn{7}{c}{2.56} \\
\hline
\end{tabular}

3. Degree of metallization (DOM) obtained from Eq. (1) is reported in the Fig. 3. Higher degree of metallization of $96.2 \%, 96.9 \%$ and $97.6 \%$ are obtained for parameters $1000^{\circ} \mathrm{C}, 2 \mathrm{~h} ; 1000^{\circ} \mathrm{C}, 3 \mathrm{~h}$; and $1000^{\circ} \mathrm{C}, 4 \mathrm{~h}$ respectively. This reveals that the metallization is nearly saturated at this temperature parameter of $1000^{\circ} \mathrm{C}$ and might not show an increasing trend with further increase in time of reduction. Similar trend is also observed for the experiments at $900^{\circ} \mathrm{C}, 3 \mathrm{~h}$ and $900^{\circ} \mathrm{C}, 4 \mathrm{~h}$ parameters. Hence to know about the maximum extent of metallization, there is a need for extended experiments at further higher temperatures.

$$
\operatorname{DOM}(\%)=\frac{F e(M e t)}{(F e(T))} \times 100
$$

Physical analysis of MIP for true and apparent density is shown in the Table 4. True density of pure iron powder reported in the literature will be in the range of 7.85 to 7.89 $\mathrm{g} / \mathrm{cc}$. It is observed that, with increase in time of reduction at a particular temperature of reduction, true density of MIP is increasing, signifying the increase in metallization. This trend is also observed with increase in reduction temperature at a particular time of reduction. Higher true density is obtained at $1000^{\circ} \mathrm{C}, 2 \mathrm{~h} ; 1000^{\circ} \mathrm{C}, 3 \mathrm{~h}$; and $1000^{\circ} \mathrm{C}$, $4 \mathrm{~h}$ parameters. These results are in line with the results of degree of metallization. Unlike true density, apparent density of powder samples is not only dependent on the chemical composition but also dependent on the shape, size

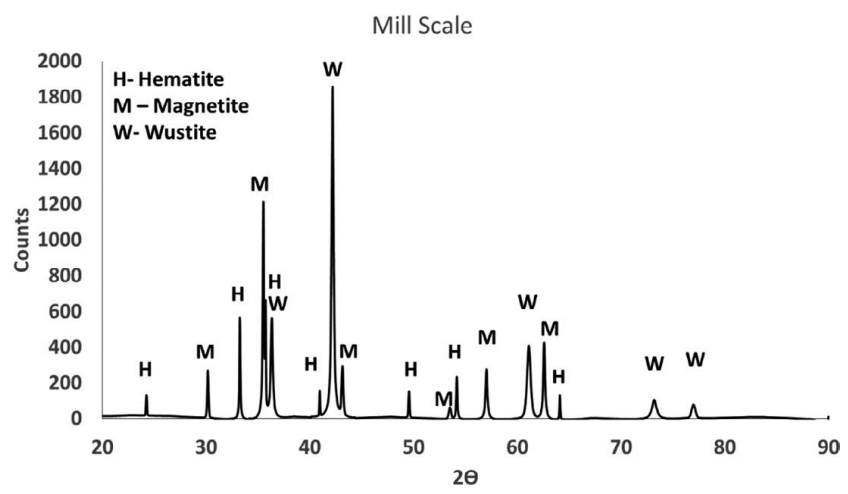

Fig. 1. XRD analysis of Mill Scale.

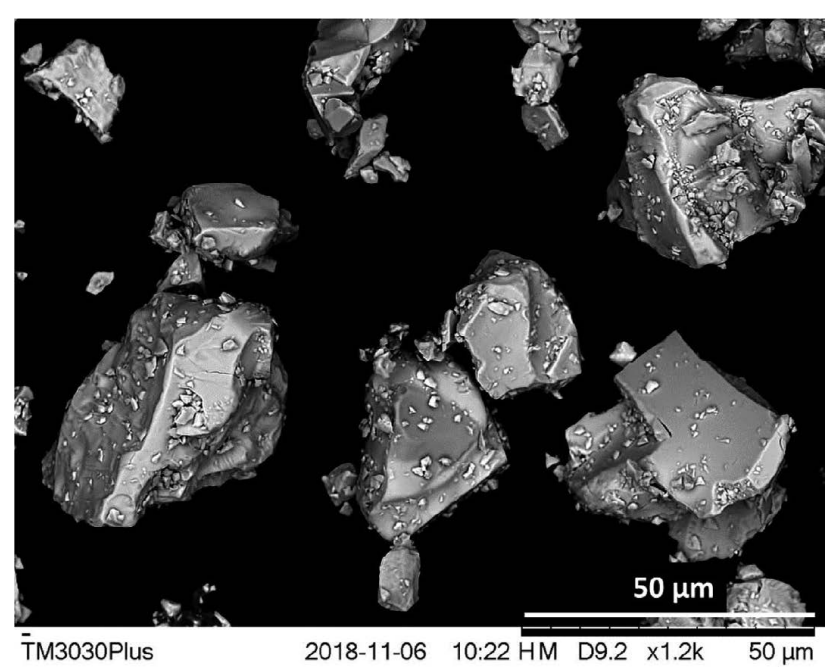

Fig. 2. SEM morphology of Mill Scale. 
Table 3. Chemical analysis of MIP

\begin{tabular}{|c|c|c|c|c|c|c|c|c|c|c|}
\hline Sample & $\mathrm{Fe}(\mathrm{T})$ & $\mathrm{FeO}$ & $\begin{array}{c}\mathrm{Fe} \\
\text { (Met) }\end{array}$ & $\mathrm{CaO}$ & $\mathrm{SiO} 2$ & $\mathrm{~S}$ & $\mathrm{MnO}$ & $\mathrm{A} 12 \mathrm{O} 3$ & $\mathrm{C}$ & $\mathrm{P}$ \\
\hline $600 / 1$ & 75.37 & 71.21 & 4.4 & 0.16 & 0.4 & 0.005 & 0.57 & 0.15 & 0.122 & 0.019 \\
\hline $600 / 2$ & 78.84 & 65.53 & 17.6 & 0.18 & 0.45 & 0.008 & 0.59 & 0.16 & 0.063 & 0.019 \\
\hline $600 / 3$ & 84.6 & 55.8 & 36 & 0.2 & 0.45 & 0.011 & 0.71 & 0.18 & 0.134 & 0.022 \\
\hline $600 / 4$ & 86.46 & 50.44 & 46.1 & 0.21 & 0.48 & 0.012 & 0.75 & 0.19 & 0.114 & 0.021 \\
\hline $700 / 1$ & 82.8 & 68.3 & 27.2 & 0.17 & 0.37 & 0.006 & 0.62 & 0.16 & 0.079 & 0.018 \\
\hline $700 / 2$ & 83.9 & 61.4 & 34.4 & 0.32 & 0.66 & 0.006 & 0.75 & 0.16 & 0.109 & 0.026 \\
\hline $700 / 3$ & 83.95 & 58.82 & 37 & 0.32 & 0.56 & 0.007 & 0.78 & 0.16 & 0.097 & 0.021 \\
\hline $700 / 4$ & 87.79 & 42.05 & 54.4 & 0.33 & 0.53 & 0.007 & 0.79 & 0.17 & 0.099 & 0.021 \\
\hline $800 / 1$ & 84.5 & 56 & 39 & 0.3 & 0.55 & 0.005 & 0.73 & 0.15 & 0.083 & 0.02 \\
\hline $800 / 2$ & 84.75 & 52.5 & 43 & 0.2 & 0.48 & 0.004 & 0.73 & 0.19 & 0.064 & 0.213 \\
\hline $800 / 3$ & 86.24 & 47.4 & 49.1 & 0.03 & 0.12 & 0.004 & 0.67 & 0.195 & 0.08 & 0.018 \\
\hline $800 / 4$ & 89.64 & 38.5 & 60 & 0.22 & 0.39 & 0.005 & 0.65 & 0.19 & 0.094 & 0.213 \\
\hline $900 / 1$ & 86.4 & 53 & 45 & 0.01 & 0.43 & 0.001 & 0.61 & 0.13 & 0.028 & 0.022 \\
\hline $900 / 2$ & 87.4 & 47 & 51 & 0.01 & 0.47 & 0.003 & 0.72 & 0.13 & 0.03 & 0.022 \\
\hline $900 / 3$ & 93.82 & 18.71 & 79.4 & 0.01 & 0.9 & 0.001 & 0.72 & 0.18 & 0.038 & 0.029 \\
\hline $900 / 4$ & 94.29 & 16.75 & 81.4 & 0.08 & 0.86 & 0.002 & 0.76 & 0.19 & 0.023 & 0.034 \\
\hline $1000 / 1$ & 87.5 & 47.1 & 51.08 & 0.01 & 0.94 & 0.001 & 0.7 & 0.19 & 0.02 & 0.023 \\
\hline $1000 / 2$ & 96.61 & 4.7 & 93 & 0.12 & 1.1 & 0.001 & 0.77 & 0.19 & 0.029 & 0.027 \\
\hline $1000 / 3$ & 97.10 & 3.9 & 94.1 & 0.01 & 0.9 & 0.001 & 0.73 & 0.17 & 0.021 & 0.089 \\
\hline $1000 / 4$ & 97.11 & 3 & 94.8 & 0.06 & 0.97 & 0.001 & 0.79 & 0.21 & 0.04 & 0.023 \\
\hline
\end{tabular}

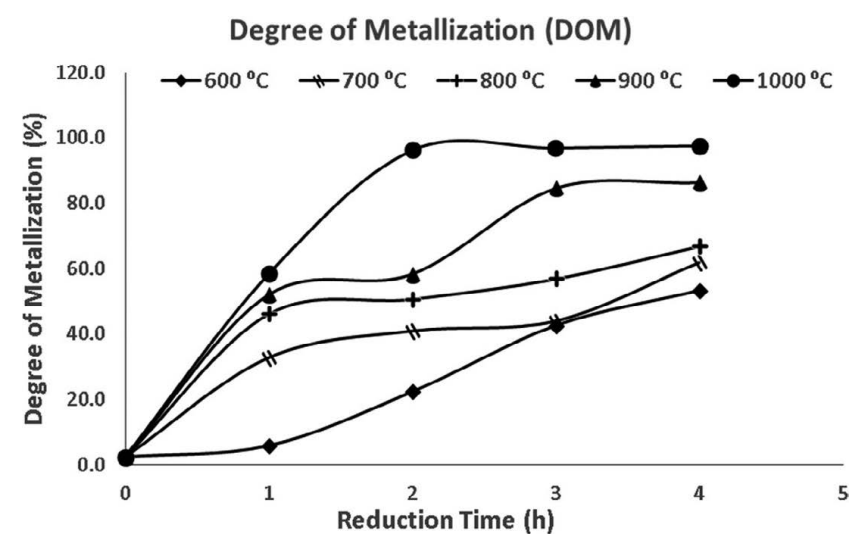

Fig. 3. Degree of Metallization of MIP.

and packing tendency of the MIP obtained. As the reduction proceeds with different temperature and time combination MIP with different purity and compositions are produced. Particle size and porosity of magnetite, wustite and iron behaves differently. Hence, no proper conclusions can be drawn based on the apparent density results of MIP. However, it is understood that, apparent density of MIP with highest metallization for $1000^{\circ} \mathrm{C}, 3 \mathrm{~h}$ and $1000^{\circ} \mathrm{C}, 4 \mathrm{~h}$ samples are in the range of $1.65-1.69 \mathrm{~g} / \mathrm{cc}$.

The sintering tendency of iron powder is temperature and time dependent. Sintering behaviour of MIP at various reaction parameters is shown in the Fig. 4. It depicts that, MIP synthesized with parameters falling in Zone A (i.e. top left portion of the first white line) are not sintered but stays in
Table 4. Physical analysis of MIP.

\begin{tabular}{|c|c|c|c|c|c|}
\hline Sample & $\begin{array}{c}\text { True } \\
\text { Density } \\
(\mathrm{g} / \mathrm{cc})\end{array}$ & $\begin{array}{c}\text { Apparent } \\
\text { Density } \\
(\mathrm{g} / \mathrm{cc})\end{array}$ & Sample & $\begin{array}{c}\text { True } \\
\text { Density } \\
(\mathrm{g} / \mathrm{cc})\end{array}$ & $\begin{array}{c}\text { Apparent } \\
\text { Density } \\
(\mathrm{g} / \mathrm{cc})\end{array}$ \\
\hline $600 / 1$ & 5.6685 & 2.08 & $800 / 3$ & 6.47565 & 1.98 \\
\hline $600 / 2$ & 5.90605 & 2.04 & $800 / 4$ & 6.8145 & 1.98 \\
\hline $600 / 3$ & 6.27805 & 1.96 & $900 / 1$ & 6.12115 & 2 \\
\hline $600 / 4$ & 6.7035 & 1.905 & $900 / 2$ & 6.644 & 1.98 \\
\hline $700 / 1$ & 5.87875 & 1.8515 & $900 / 3$ & 7.2049 & 2.04 \\
\hline $700 / 2$ & 6.2934 & 1.725 & $900 / 4$ & 7.3133 & 2 \\
\hline $700 / 3$ & 6.4526 & 1.63 & $1000 / 1$ & 6.6064 & 1.78 \\
\hline $700 / 4$ & 6.66645 & 2.04 & $1000 / 2$ & 7.6433 & 1.585 \\
\hline $800 / 1$ & 6.2995 & 1.98 & $1000 / 3$ & 7.665 & 1.665 \\
\hline $800 / 2$ & 6.3107 & 1.85 & $1000 / 4$ & 7.6965 & 1.692 \\
\hline
\end{tabular}

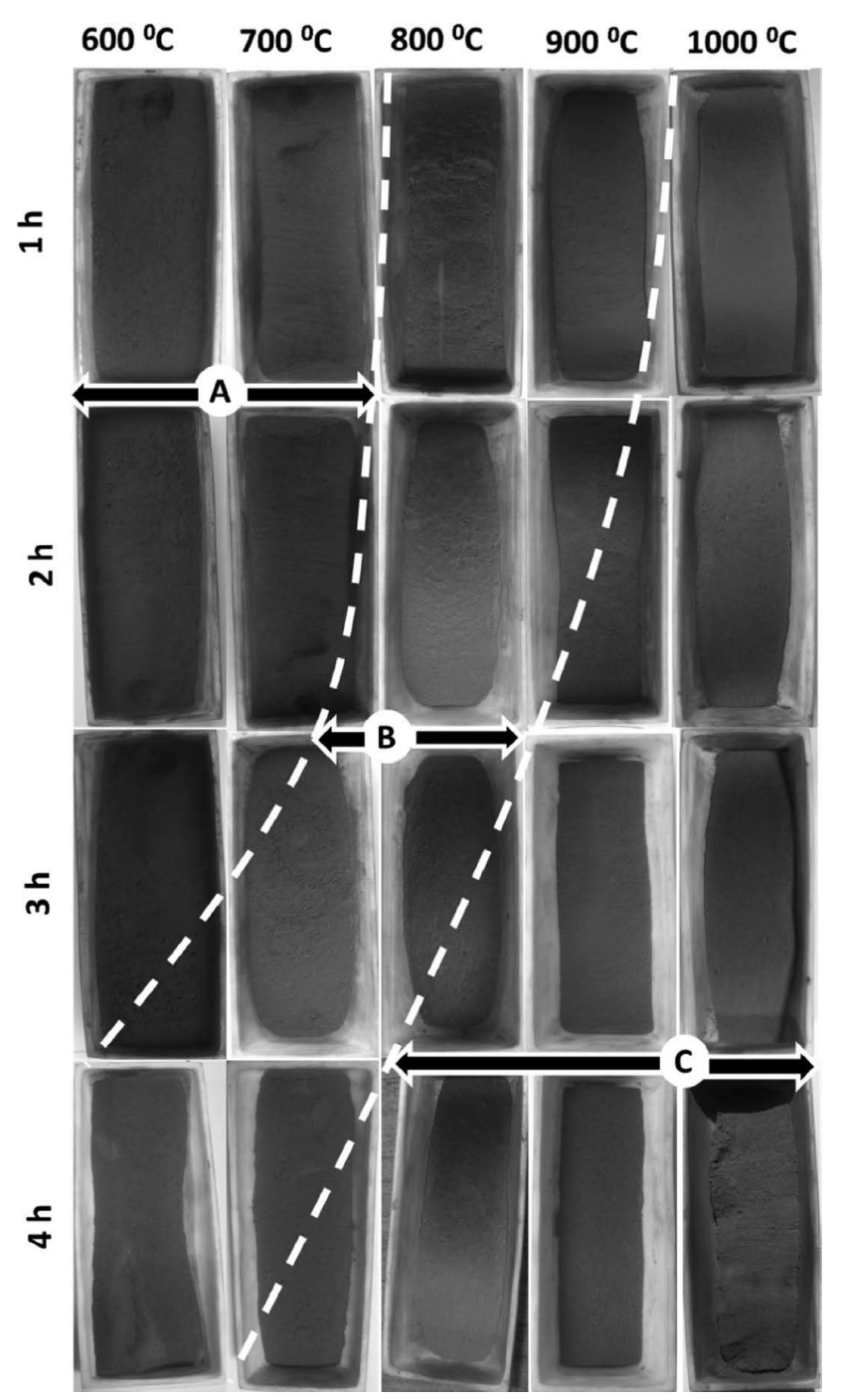

Fig. 4. Sintering behaviour of MIP.

the form of loose powder, MIP synthesized with parameters falling in the Zone B (i.e., between the two white lines) are slightly sintered and shown partial caking tendency and MIP synthesized with parameters falling in the Zone $\mathrm{C}$ (i.e., bottom right portion of the second white line) are com- 
pletely sintered forming a solid cake. Sintering of MIP can be attributed to the formation of metallic iron from oxide which upon further exposure to increasing temperatures and time intervals of reduction undergoes interparticle joining and strengthening. Results showcased in the Table 3 also reveals an increase in $\mathrm{Fe}$ (Met) values from Zone A to Zone $\mathrm{B}$ to Zone C. Sintering can be easily visualized by volume shrinkage of the product formed in respective sample boats, with highest volume in Zone A and lowest volume in Zone C. Decrease in rate of metallization due to sintering of the reduced product is reported by Pineau and co-workers. ${ }^{24)} \mathrm{A}$ similar observation of saturation of metallization (decrease in rate of metallization) is observed for experimental parameters $1000^{\circ} \mathrm{C}, 2 \mathrm{~h} ; 1000^{\circ} \mathrm{C}, 3 \mathrm{~h} ; 1000^{\circ} \mathrm{C}, 4 \mathrm{~h}$ and $900^{\circ} \mathrm{C}$, $3 \mathrm{~h}$; and $900^{\circ} \mathrm{C}, 4 \mathrm{~h}$ which can be attributed to the sintering behaviour of MIP as these parameters are in match with the experimental parameters falling under zone C. From the Figs. 3 and 4 it can be observed that, parameters in zone A with DOM $<40 \%$ experienced a constant increase in DOM with time and parameters in Zone $\mathrm{C}$ with DOM $>60 \%$, where sintering behaviour is predominant, experienced a saturation in DOM with time. Interestingly in Zone B, where the $40 \%<\mathrm{DOM}<60 \%$ and slight sintering is under progress, an inconsistent increase in DOM with intermittent saturation of DOM is observed. In particular, parameters which fall under the category of shift between Zone A to
Zone B like, $600^{\circ} \mathrm{C} 3-4 \mathrm{~h}, 700^{\circ} \mathrm{C} 2-3 \mathrm{~h}$ and Zone B to Zone $\mathrm{C}$ like, $800^{\circ} \mathrm{C} 2-3 \mathrm{~h}, 900^{\circ} \mathrm{C} 1-2 \mathrm{~h}$ face a slight saturation in DOM. Thus, this inconsistent increase in DOM in Zone B is assumed to be the interplay between sintering and kinetics of reduction which are dependent on temperature of reduction and time of reduction. On the other hand, increase in $\mathrm{DOM}$ for the parameters $1000^{\circ} \mathrm{C}, 0 \mathrm{~h}$ to $1000^{\circ} \mathrm{C}, 2 \mathrm{~h}$ in Zone $\mathrm{C}$ is assumed to be due to enhanced reduction along with sintering at higher temperatures. However, other than saturation of DOM with time for high temperature and time parameters in Zone $\mathrm{C}$ and smooth increase in DOM for parameters in Zone A, no concrete conclusions can be drawn on the inconsistent behaviour in Zone B.

Scanning electron microscopy results of MIP synthesized at various parameters is shown in the Fig. 5. From the image, it is evident that, the formation of iron from wustite is clearly visible by appearance of whisker formation which gradually turns spongy. Presence of magnetite/wustite is also identified by solid morphology. The predicted change in the morphology is also supported by X-ray diffraction studies. Results of XRD peak evaluation for all the samples are denoted individually in the left superscript using M (Magnetite), W (Wustite) and I (Iron) terminologies for each parameter in the Fig. 5. Considering the example of parameter $1000^{\circ} \mathrm{C}$ reduction temperature, SEM micrograph of $1000^{\circ} \mathrm{C}, 1 \mathrm{~h}$ depicts the presence of
$1 \mathrm{~h}$
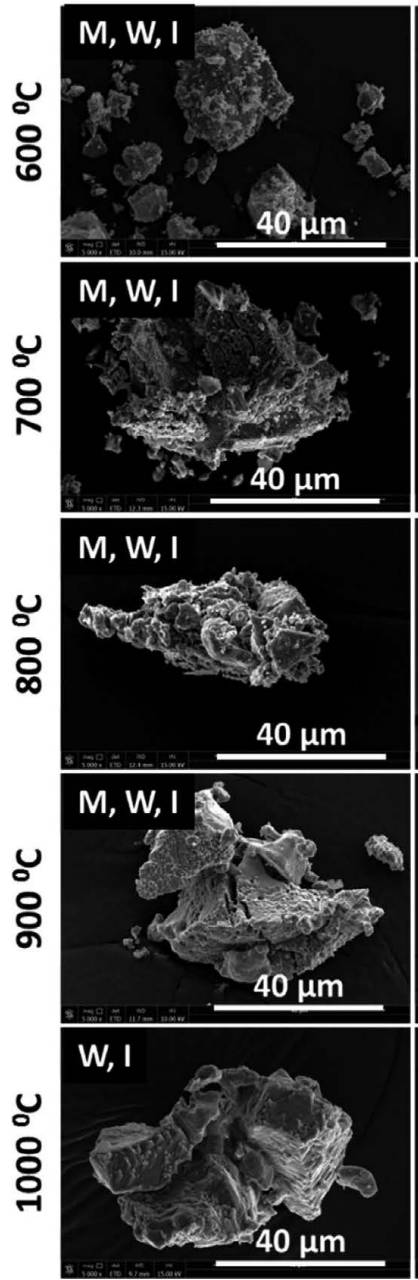

$\mathbf{2 h}$
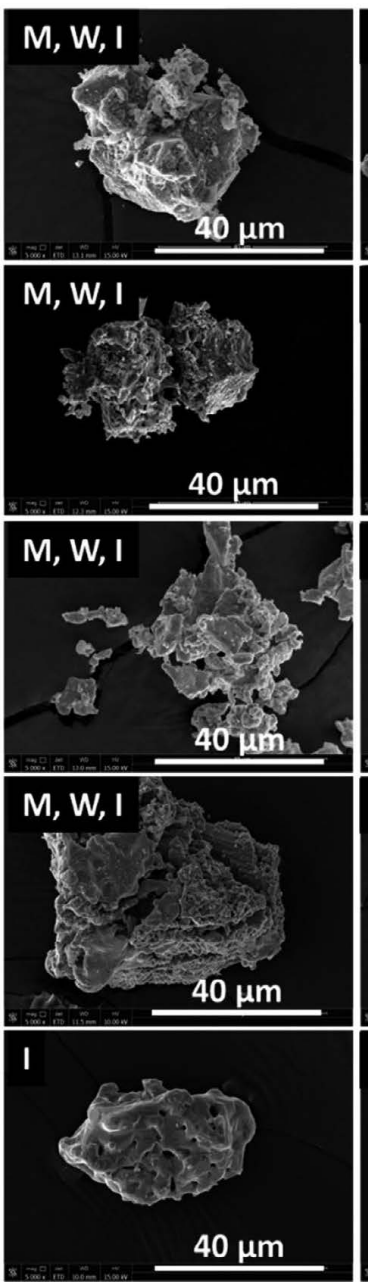

$3 \mathbf{h}$
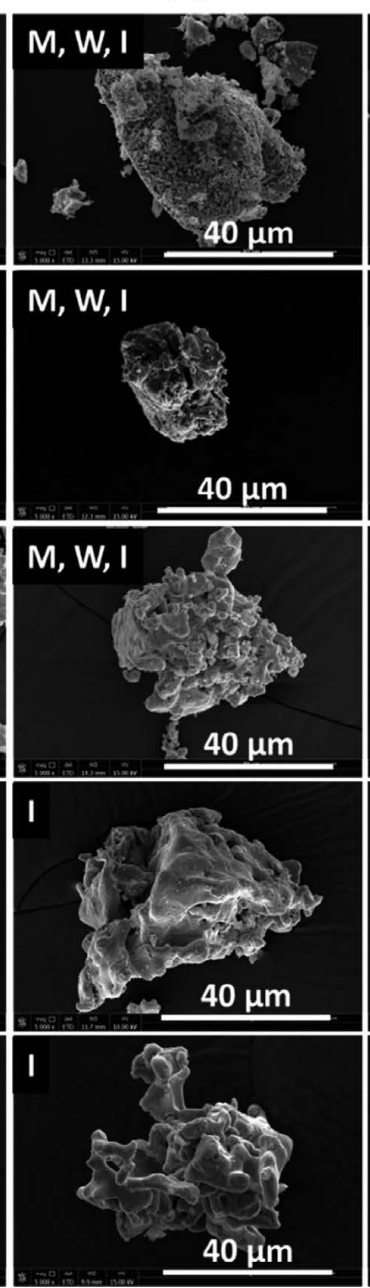

$4 \mathrm{~h}$

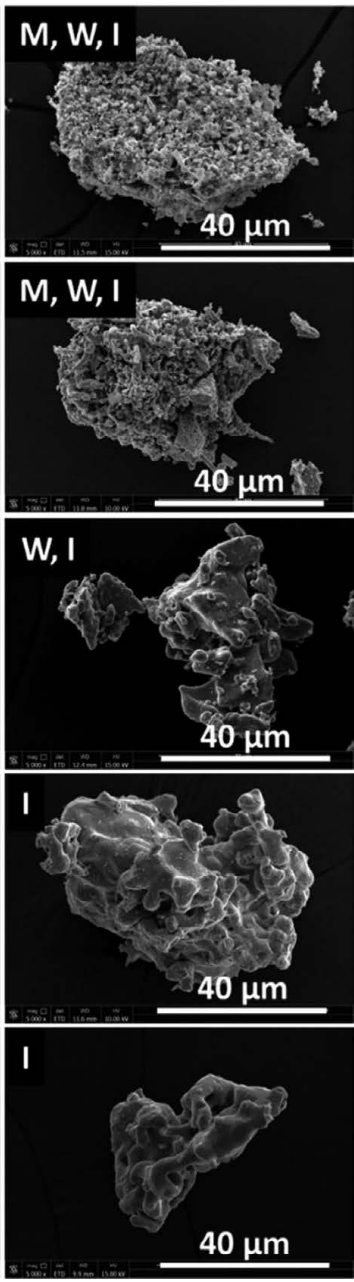

Fig. 5. SEM morphology of MIP along with phase identification. 
both solid as well early whiskers formation. At $1000^{\circ} \mathrm{C}$, $2 \mathrm{~h}$ the solid morphology slowly turns into spongy one and the whiskers were completely occupied. At $1000^{\circ} \mathrm{C}$, $3 \mathrm{~h}$ and $4 \mathrm{~h}$, the morphology turns completely spongy and smoothened signifying the formation of complete iron. Similar results are also seen for $900^{\circ} \mathrm{C} 1 \mathrm{~h}, 2 \mathrm{~h}, 3 \mathrm{~h}, 4$ $\mathrm{h}$ parameters, where the morphology of MIP shifts from solid-whisker to spongy-whisker to finally a spongy one with increase in time of reduction. Spongy iron formation is observed at higher temperatures and higher time of reduction while, whisker form of iron is observed at lower temperatures as well as at lower time of reduction even at higher temperature of reduction. This is attributed to the metallization, where the whisker formation is observed during the conversion of wustite to iron during early metallization. Similar observation of presence of spongy iron at higher temperatures and whisker form of iron at low temperatures is reported by Bagatini and co-workers. ${ }^{2)}$ SEM and XRD results shown in Fig. 5 also supports the dependency of sintering on metallic iron formation. Sintering is predominant at the parameters $900^{\circ} \mathrm{C} 3 \mathrm{~h}, 4 \mathrm{~h}$ and $1000^{\circ} \mathrm{C} 2 \mathrm{~h}, 3 \mathrm{~h}, 4 \mathrm{~h}$ where metallic iron formation is significantly high.

\subsection{Effect of Temperature and Time of Reduction}

Higher temperatures lead to higher degree of metallization as well as high sintering tendency of iron powder, thus making the product cake so hard to process further. Higher the time of reduction, higher must be the degree of metallization. But the degree of metallization of MIP at higher temperatures $\left(>900^{\circ} \mathrm{C}\right)$, show minimal difference between $3 \mathrm{~h}$ and $4 \mathrm{~h}$ time of reduction. This is due to saturation of reduction reaction for the given set of parameters of temperature and gas flow. Increasing either temperature or gas flow or both would increase the extent of reaction thus improving degree of metallization. Increase in metallization by increase in gas flow is attributed to the increase in bulk gas concentration of reducing gas, increase in gas diffusion and increase in gas absorption. ${ }^{12)}$ Increase in reduction temperatures for a constant gas flow also results in increased degree of metallization due to increase in gas-solid reaction kinetics.

\subsection{Extended Matrix Trials}

As most of the properties of MIP are good at the extreme end of temperature and time combinations of the normal experimental matrix, extended matrix trials are performed at reduction temperatures $1100^{\circ} \mathrm{C}, 1200^{\circ} \mathrm{C}$ and $1300^{\circ} \mathrm{C}$ at $4 \mathrm{~h}$ reduction time. Obtained results of DOM $(98.3 \%$, $99.18 \%$ and $99.28 \%$ for ascending temperature parameters respectively) and chemical analysis (as shown in Table 5) showcase that, iron powder with $>99 \%$ metallization,

Table 5. Chemical analysis of MIP in extended trials.

\begin{tabular}{llllllllllll}
\hline Sample & $\mathrm{Fe}(\mathrm{T})$ & $\mathrm{FeO}$ & $\begin{array}{c}\mathrm{Fe} \\
(\mathrm{Met})\end{array}$ & $\mathrm{CaO}$ & $\mathrm{SiO} 2$ & $\mathrm{~S}$ & $\mathrm{MnO}$ & $\mathrm{A} 12 \mathrm{O} 3$ & $\mathrm{C}$ & $\mathrm{P}$ \\
\hline $1100 / 4$ & 96.64 & 1.03 & 95 & 0.54 & 0.73 & 0.001 & 0.85 & 0.31 & 0.03 & 0.025 \\
$1200 / 4$ & 96.79 & 0.51 & 96 & 0.61 & 0.78 & 0.001 & 0.85 & 0.35 & 0.03 & 0.027 \\
$1300 / 4$ & 97 & 0.9 & 96.3 & 0.55 & 0.67 & 0.001 & 0.85 & 0.39 & 0.03 & 0.022
\end{tabular}

$\mathrm{Fe}(\mathrm{T})>96.5 \%$ and $\mathrm{Fe}(\mathrm{Met})>96 \%$ is obtained at temperatures $1200^{\circ} \mathrm{C}$ and $1300^{\circ} \mathrm{C}$. The product cake obtained is of high purity possible, heavily sintered and is very hard to grind manually. Hence, ball mill grinding is introduced for grinding MIP cakes to get MIP.

\subsection{Effect of Raw Material Particle Size}

Effect of raw material size on the metallization is also studied by collecting three different size fractions of raw materials, i.e., minus 75 micron, minus 45 micron and minus 25 micron and comparing the obtained results with that of general raw material of minus 150 microns size. All the sample are evaluated for chemical composition after reduction at $1100^{\circ} \mathrm{C}, 4 \mathrm{~h}$ parameters and obtained chemical analysis results are reported in the Table 6. It is evident form the results that, the $\mathrm{Fe}$ (Met) content for minus 150 microns, minus 75 microns, minus 45 microns and minus 25 microns are $95 \%, 95 \%, 95.4 \%$ and $95.4 \%$ respectively, which portrays very minimal or negligible difference. Sen and co-workers reported that, the reduction extent of mill scale decreased with decrease in mill scale particle size, which is attributed to the decrease in mill scale column permeability while reduction with CO gas. ${ }^{6}$ ) El-Hussiny and co-workers also studied the particle size dependency of mill scale on extent of reduction with hydrogen gas and reported that, reduction extent of mill scale in the form of briquettes increased with decrease in particle size of the mill scale from $0.8 \mathrm{~mm}$ to $0.125 \mathrm{~mm}$. This is due to increase in available surface area for reduction. ${ }^{12)}$ In the present work, as the reducing media is hydrogen gas permeability issue doses not persist and as the mill scale particle sizes are all in the micron range ( $<150$ micron), the surface area change might not be significant. Hence the effect of raw material particles size stands negligible.

\subsection{Effect of Product Grinding}

MIP produced at $1000^{\circ} \mathrm{C}, 4 \mathrm{~h}$ reduction is subjected to various grinding intervals using lab scale mono mill. Obtained results represents an increase in apparent density with increase in grinding time as shown in the Fig. 6. Apparent density of MIP increased from $1.692 \mathrm{~g} / \mathrm{cc}$ for normal hand ground sample to $2.631 \mathrm{~g} / \mathrm{cc}$ for $1 \mathrm{~h}$ mono mill grinding at $150 \mathrm{rpm}$. This increase in apparent density is not only attributed to the decrease in particle size but also the decrease in internal porosity of the powdered fines due to the impact force of grinding media while grinding.

\subsection{Application Comparative Study}

To explore the best value of mill scale by recycling through direct reduction route is to produce potential iron

Table 6. Chemical analysis of MIP produced from various raw material sizes.

\begin{tabular}{cccccccccccc}
\hline Sample & $\mathrm{Fe}(\mathrm{T})$ & $\mathrm{FeO}$ & $\begin{array}{c}\mathrm{Fe} \\
\text { (Met) }\end{array}$ & $\mathrm{CaO}$ & $\mathrm{SiO} 2$ & $\mathrm{~S}$ & $\mathrm{MnO}$ & $\mathrm{A} 12 \mathrm{O} 3$ & $\mathrm{C}$ & $\mathrm{P}$ \\
\hline$-150 \mu$ & 96.64 & 1.03 & 95 & 0.54 & 0.73 & 0.001 & 0.85 & 0.31 & 0.03 & 0.025 \\
$-75 \mu$ & 95.85 & 0.3 & 95 & 0.54 & 0.81 & 0.001 & 0.596 & 0.843 & 0.03 & 0.02 \\
$-45 \mu$ & 96.18 & 0.4 & 95.4 & 0.54 & 0.66 & 0.001 & 0.59 & 0.748 & 0.03 & 0.03 \\
$-25 \mu$ & 96.11 & 0.3 & 95.4 & 0.54 & 0.65 & 0.001 & 0.58 & 0.753 & 0.03 & 0.024
\end{tabular}


powder. Information regarding specifications of various grades of iron powders being used in the market for various applications is shown in the Table $7{ }^{25,26)}$ Specification comparison study reveals that MIP stands in par with commercial powders for application in nutrition supplements, body warmers, water purification and sound insulators. Even though the powder has advantage in terms of iron content, carbon, nitrogen, manganese, phosphorous, sulphur, appar-

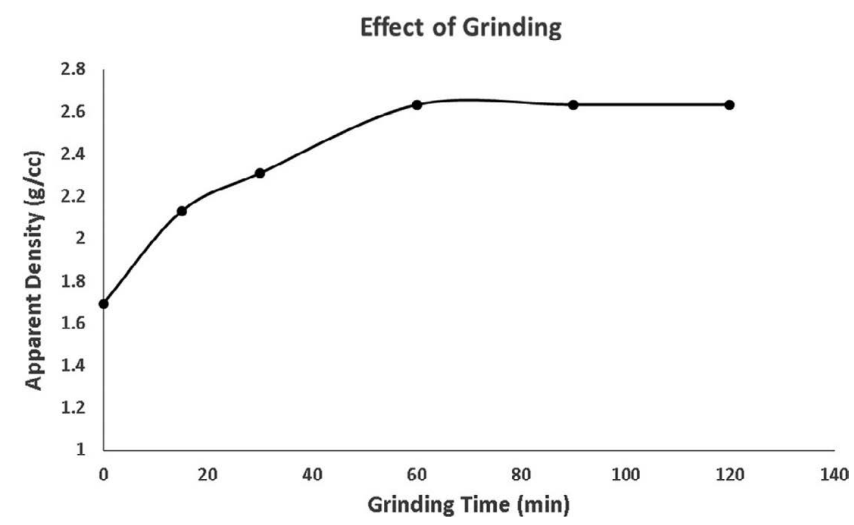

Fig. 6. Effect of grinding time on apparent density of MIP. ent density and particle size, higher oxygen and silicon contents make our powder stand a bit away from commercial iron powders. This is attributed to the non-ferrous impurities present in the raw material, which are being carried in the product as well.

\section{Conclusions}

Iron powders (MIP) with $>99 \%$ degree of metallization $(97 \% \mathrm{Fe}(\mathrm{T}),>96 \% \mathrm{Fe}$ (met)) and $2.63 \mathrm{~g} / \mathrm{cc}$ apparent density are synthesized in a single step using steel plant by product mill scale as a raw material. Higher temperatures of reduction and higher time of reduction led to high purity of iron powder, which is also reflected in its true density measurement.

- Effect of temperature and time of reduction on the morphology of MIP is studied and formation of iron through whisker and spongy nature is clearly visible. This change in morphology from solid (Wustite) to whiskers (iron) to finally spongy (iron) is also supported by XRD evaluation.

- Effect of sintering on the degree of metallization reveals that the sintering tendency of MIP hinders the extent

Table 7. Application comparative study of iron powders.

\begin{tabular}{|c|c|c|c|c|c|c|c|c|c|c|c|c|}
\hline Material & Application & $\mathrm{Fe}(\mathrm{T})$ & $\begin{array}{c}\mathrm{Fe} \\
(\mathrm{Met})\end{array}$ & $\mathrm{C}$ & $\mathrm{Si}$ & $\mathrm{N}$ & $\mathrm{Mn}$ & $\mathrm{P}$ & $\mathrm{S}$ & $\mathrm{O}$ & $\mathrm{AD}$ & PSD \\
\hline MIP & & $>97$ & $>96$ & $<0.03$ & $<0.65$ & & $<0.36$ & $<0.03$ & $<0.02$ & $<1$ & $2.3-3.6$ & $<150$ \\
\hline JIP $270 \mathrm{M}$ & Powder Metallurgy & $>98.5$ & & $<0.02$ & $<0.15$ & & $<0.40$ & $<0.015$ & $<0.02$ & & $2.6-2.8$ & $<150$ \\
\hline CIP CS & Powder Metallurgy & $>99.5$ & & $<0.03$ & & $<0.01$ & & & & $0.1-0.3$ & & D50: $6-7$ \\
\hline JIPB80 & Friction Materials & $>98$ & & $<0.05$ & $<0.15$ & & $<0.40$ & $<0.02$ & $<0.02$ & & $2.2-2.45$ & $<180$ \\
\hline CIP EM & $\begin{array}{c}\text { Electronic } \\
\text { Components }\end{array}$ & $>97$ & & $0.65-0.85$ & & $0.6-0.8$ & & & & $0.1-0.3$ & & D50: $4.5-6$ \\
\hline JIP MG270H & $\begin{array}{l}\text { Magnetic } \\
\text { Materials }\end{array}$ & $>98.5$ & & $<0.05$ & $<0.15$ & & $<0.40$ & $<0.02$ & $<0.02$ & & $2.62-2.82$ & $<150$ \\
\hline CIP ER & $\begin{array}{l}\text { Microwave } \\
\text { absorption }\end{array}$ & $>97$ & & $<1$ & & $<1$ & & & & $<0.8$ & & D50: 4.5 \\
\hline JIP 303A60 & $\begin{array}{l}\text { Deoxidizing } \\
\text { materials }\end{array}$ & $>99$ & & $<0.02$ & $<0.1$ & & $0.15-0.25$ & $<0.02$ & $<0.02$ & $<0.3$ & $2.85-3.05$ & $<250$ \\
\hline CIP OS & $\begin{array}{l}\text { Metal Injection } \\
\text { Moulding }\end{array}$ & $>97.5$ & & $0.7-0.9$ & & $0.5-0.9$ & & & & $0.6-0.9$ & & D50: $3.4-4.4$ \\
\hline JIP WH-100 & Welding Materials & $>98$ & & $<0.1$ & $<0.2$ & & $<0.4$ & $<0.02$ & $<0.02$ & & & $<250$ \\
\hline CIP EN & Diamond Tools & $>97.5$ & & $<0.9$ & & $<1$ & & & & $<0.6$ & & D50: $3.9-5.2$ \\
\hline JIP G & $\begin{array}{c}\text { Gas Cutting } \\
\text { Agents }\end{array}$ & $>98$ & & $<0.1$ & & & & & $<0.025$ & & & $<180$ \\
\hline CIP OF & $\begin{array}{c}\text { Nutrition } \\
\text { Supplement }\end{array}$ & $>97$ & & $<1.3$ & & $<0.3$ & & & & $<1.4$ & & D50: 5.2 \\
\hline JIP K-100T & Body Warmers & & $>90$ & & & & & & & & $2.4-2.8$ & $<180$ \\
\hline $\begin{array}{c}\text { ZVI MICRO } \\
\text { SPHERES } \\
200\end{array}$ & $\begin{array}{c}\text { Ground } \\
\text { Remediation }\end{array}$ & $>97.5$ & & $<1$ & & $<1$ & & & & $<0.5$ & & D50: 5.2 \\
\hline JIP 300R & $\begin{array}{c}\text { Chemical } \\
\text { Reaction Agents }\end{array}$ & & & $<0.25$ & $<0.05$ & & $<0.3$ & $<0.025$ & $<0.025$ & $<1.2$ & & $<250$ \\
\hline FeroxTarget & Water Purification & $>95.48$ & & $<2.10$ & & & & & $<0.08$ & & 2.3 & $<45$ \\
\hline JIP S-100 & Sound Insulators & $>70$ & & & & & & & & & & $<150$ \\
\hline MICRO44 & Water Purification & 94-99 & & $<3$ & & & & & $<0.15$ & & $2.2-3.6$ & $<45$ \\
\hline
\end{tabular}


of metallization with time especially at parameters $900^{\circ} \mathrm{C}$, $3-4 \mathrm{~h}$ and $1000^{\circ} \mathrm{C}, 2-4 \mathrm{~h}$ where sintering is predominant due to formation of more metallic iron. Zone (Zone A, B, C) wise dependency of sintering on the degree of metallization is also explained. Extended matrix trials conducted at higher temperatures of reduction resulted in iron powders with high metallization.

- Effect of raw material size on the purity of MIP is negligible. Mechanical grinding of MIP using mini ball mill has improve their $\mathrm{AD}$, which is one the prominent specification for powder iron applications.

- With its purity at one end and the particle size and apparent density at other, this unique powdered iron product will open new applications in nutrition supplements, body warmers, water purification and sound insulators, etc.

- Further scope of research appears to be in improving the raw material quality by defined pre-treatment techniques, which would make the synthesized powder open to further applications such as powder metallurgy, friction materials, electronic components, magnetic materials, microwave absorption, deoxidizing materials, metal injection moulding, welding materials, diamond tools, gas cutting agents, ground remediation, chemical reagents, etc.

\section{REFERENCES}

1) L. Camci, S. Aydin and C. Arslan: Turk. J. Eng. Environ. Sci., 26 (2002), 37.

2) M. C. Bagatini, V. Zymla, E. Osorio and A. C. F. Vilela: ISIJ Int., 51 (2011), 1072

3) N. M. Gaballah, A. F. Zikry, M. G. Khalifa, A. B. Farag, A. El-Hussiny and M. E. H. Shalabi: Open J. Inorg. Non-Metall. Mater., 3 (2013), 23.

4) B. Das, S. Prakash, P. S. R. Reddy and V. N. Misra: Resour. Conserv.
Recycl., 50 (2007), 40.

5) M. I. Martin, F. A. Lopez and J. M. Torralba: Ironmaking Steelmaking, 39 (2012), 155.

6) R. Sen, S. Dehiya, U. Pandel and M. K. Banerjee: Procedia Earth Planet. Sci., 11 (2015), 8.

7) N. A. El-Hussiny, F. M. Mohamed and M. E. H. Shalabi: Sci. Sinter., 43 (2011), 21.

8) T. Umadevi, A. Brahmacharyulu, P. Karthik, P. C. Mahapatra, M. Prabhu and M. Ranjan: Ironmaking Steelmaking, 39 (2012), 222.

9) M. Eissa, A. Ahmed and E. El-Fawkhry: J. Metall., 926028 (2015), 1 .

10) R. Farahat, M. Eissa, G. Megahed and A. Baraka: Steel Grips, 8 (2010), 88

11) N. A. El-Hussiny and M. E. H. Shalabi: Powder Technol., 205 (2011), 217.

12) N. A. El-Hussiny, H. H. Abdul-Waheb, M. M. Ali, A. A. Omar, M. E. H. Shalabi and M. R. Moharm: Open Access Libr. J., 1 (2014), 1.

13) R. S. Anand, P. Kumar and D. N. Paswan: IOSR J. Mech. Civil Eng., 13 (2016), 49.

14) K. S. Sista and S. Dwarapudi: ISIJ Int., 58 (2018), 999.

15) O. Benchiheub, S. Mechachti, S. Serrai and M. G. Khalifa: J. Mater. Environ. Sci., 1 (2010), 267.

16) Q. Ye, H. Zhu, J. Peng, C. S. Khannan, J. Chen, L. Dai and P. Liu: Metall. Mater. Trans. B, 44B (2013), 1478.

17) Q. Ye, H. Zhu, L. Zhang, J. Ma, L. Zhou, P. Liu, J. Chen, G. Chen and J. Peng: J. Alloy. Compd., 613 (2014), 102.

18) S. Mechachti, O. Benchiheub, S. Serrai and M. E. H. Shalabi: Int. J. Sci. Eng. Res., 4 (2013), No. 5, 1467.

19) C. Joshi and N. B. Dhokey: Trans. Indian Inst. Met., 68 (2015), 31.

20) J. Shi, D. R. Wang, Y. D. He, H. B. Qi and G. Wei: Mater. Lett., 62 (2008), 3500.

21) S. Cho and J. Lee: Met. Mater. Int., 14 (2008), 193.

22) C. Guan, J. Li, N. Tan, Y. He and S. Zhang: Int. J. Hydrog. Energy, 39 (2014), 15116

$23)$ D. Wagner, O. Devisme, F. Patisson and D. Ablitzer: Sohn Int. Symp., Vol. 2, TMS, Warrendale, PA, (2006), 111.

24) A. Pineau, N. Kanari and I. Gaballah: Thermochim. Acta, 456 (2007), 75 .

25) JFE Steel Corporation, http://www.jfe-steel.co.jp/en/products/ ironpowders/index.php, (accessed 2018-09-10).

26) BSAF Carbonyl Iron Powder, https://www.dispersions-pigments. basf.com/portal/load/fid827906/CIP_General_PO_e.pdf, (accessed 2018-09-10) 